\title{
Cultural Study of Counselors and Counselees in Counseling
}

\author{
Elia Flurentina, Djoko Budi Santoso ${ }^{a}$ \\ Jurusan Bimbingan dan Konseling FIP Universitas Negeri Malang, Malang, Indonesia \\ Corresponding e-mail: elia.flurentin.fip@um.ac.id
}

\begin{abstract}
Cultural Study of Counselors and Counselees in Counseling. The purpose of this study is to explain the culture of the counselors and counselees with regard to language, values, stereotypes, social class, ethnicity, gender, age, and lifestyle aspects. This study uses qualitative approach. The cultural descriptions about the counselors' and counselees' perspective towards those aspects were very diverse and varied. Value-laden situation in counselors and counselees relationship greatly affected the success of counseling. The result of the study could be used as additional discourse for the Foundation of Socio-Cultural of Guidance and Counseling, Multicultural Counseling, and Field Study and Practice (KPL) of Guidance and Counseling course.
\end{abstract}

Keywords: culture, counselors, counselees, counseling.

\section{INTRODUCTION}

Guidance and counseling, as a professional service in the educational unit, is conducted by professional educators i.e. counselor or teacher of guidance and counseling [1]. The counselor assigned to the education unit should have specified academic and competent qualification. Thus, self-development of counselor through various strategies is needed to achieve the service quality standard. This selfdevelopment changes along with the needs of the counselee. One of the competencies of the counselor is to understand the characteristics of the individual being served. Counselors should be sensitive and responsive in following current developments, the development in society generally and the development in education particularly. The development is so fast that observations are constantly being made on the current and ongoing phenomena.

On the other hand, the counselors should meet the demand for quality of service and accountability. Cultural diversity in the community should be the basis of enrichment in counseling. The relationship between counselor and counselee is essentially a relationship between two different people. The differences occur because they come from different backgrounds, including their family environment, age, religion, gender, socio-economic, language, and so on. Culture influences one's basic values and beliefs. When individuals from different cultures attempt to relate to one another, they may begin with very different perceptions about the nature of people, what people need, and how people succeed [2].

The dynamic development of a changing society will have an impact on the changing needs and cultural values that counselor and counselee must understand. Rapid changes and dynamics in all fields, i.e. social, cultural, economic, educational, political, industrial, and information technology will have an impact on counselor and counselee behavioral changes. On the other hand, the implementation and development of professional services require up-to-date empirical studies in line with the dynamics of those changes. Counselors 
need to continue growing and developing, and make adjustments.

This study aims to (1) explain the culture of counselor in counseling in regard to language, values, stereotypes, social class, race or ethnicity, gender, age, sexual preferences, and lifestyle, (2) explain the culture of counselee in counseling in regard to language, values, stereotypes, social class, race or ethnicity, gender, age, sexual preferences, and lifestyle.

\section{METHOD}

This cultural study of counselors and counselees in counseling employs qualitative approach, which aims to present and describe the actual situation based on facts in the field. The operational guidelines of the research refer to the procedures of ethnographic qualitative studies, which is revealing the authentic behavior, mindset, and act of the subject based on the subject's cultural habits and experiences (in this case counselorcounselee). Data were obtained from several high school counselors who had provided counseling and several high school counselees who had received counseling.

Research data sources were the counselors in SMA Negeri 4 Malang and SMA Negeri 9 Malang, and the counselees from Class X, XI, and XII students in SMA Negeri 4 Malang and SMA Negeri 9 Malang who had received counseling. Data were obtained from four counselors in SMA Negeri 4 Malang (three women, one man) and four counselors in SMA Negeri 9 Malang (all women). Data from the counselees were obtained from 16 students in SMA Negeri 4 Malang (Class X: 3 students, Class XI: 7 students, and Class XII: 6 students) and 15 students in SMA Negeri 9 Malang (Class X: 9 students, Class XI: 3 students, and Class XII: 3 students).

The data was collected by the researcher with the assistance from a team of college students who had been well trained and organized to be fully prepared and understand the purpose of this research. Data collection on this study used observation techniques, in-depth interviews, documentation, and triangulation. Some record tools were utilized to facilitate data collection during observations and indepth interviews. The instruments were also intended to ensure the validity of the information if it was collected by a research team or college students.

Data analysis was completed based on [3] and Patton (1980) framework through two stages, namely analysis at the time of on-going data collection and analysis after completion of data collection. Analysis at the time of on-going data collection comprise making comments, making contact summaries, making case summaries, and making research memos. Data analysis after the completion of data collection consist of coding category system creation, data selection, data presentation, research result formulation, temporary result validation and field verification.

Checking the validity of the findings needs to be done in order to get the needed information to explain the counselor and counselee culture in the counseling. In order to obtain valid findings and interpretations, deep observations were made, tracking the conformity of results by conducting interviews, peer discussions, and checking with other data sources, i.e. learners from different classes. Furthermore, meetings with a team of data collectors to confirm and verify the findings were done. In addition, the researcher also checked whether or not the findings can be used to explain in any other setting.

\section{RESULTS AND DISCUSSION}

\subsection{Culture of Counselors in Counseling}

The culture of counselors is the views, opinions, action tendency of counselors in counseling relating to language, values, stereotypes, social class, race or ethnicity, gender, age, sexual preferences, and lifestyle. The relationship between counselor and counselee is essentially a relationship between two different people. The differences occur because they come from different backgrounds, including their family environment, age, religion, gender, socio-economic, language, and so on. Culture influences one's basic values and beliefs. When individuals from different cultures attempt to relate to one another, they may begin with very different perceptions about the nature of people, what people need, and how people succeed [2]. Cultural conflict in counseling can occur because of anxiety, mistrust, and the fear of being blamed and scolded [4].

In counseling, the main tool used is language. With regard to language, according to the counselor, the language used is easily understood by the counselee. The counselor is trying to use the correct Indonesian language. High school level counselees tend to master the language, moreover the counselees come from a good public school in Malang. Every human culture has a language. Language hasthousands in numbers and features, but all languages have some common characteristics [5]. Language serves as a communication tool. Every individual always communicates with the 
surrounding environment. During counseling process, counselors use a slightly formal language and sometimes use slang language for the purpose of friendliness. Since there are students from outside Java and Jakarta in SMA Negeri 4 and SMA Negeri 9 Malang, the use of Indonesian language by the counselor is the most appropriate choice. Moreover, there are counselors who come from outside Java as well. In terms of the use of dialect, some students from outside Java sometimes experience difficulties due to different dialects.

Language is about utilizing skills in listening, speaking, reading, and writing [6]. According to counselors, counselees generally have good language mastery, although some counselees still have limited vocabulary. The language used by counselors and counselees varies from slang language and regional languages to native languages. However, some counselees are still having monotonous language. According to the counselor, slang is sometimes used in counseling to make counselee feel more comfortable. There are some slang words that are commonly used in social media language, such as baper, alay, PHP and others. Slang language is used by counselors in counseling situations and in other situations. However, some counselors avoid the use of slang language because they are not used in using it. This can be understood; sometimes miscommunication occurs if the counselor and counselee are not in the same communication context.

Furthermore, the culture of counselors relates to value. Value is a tendency of preferences based on a particular conception, that is, what people want and like. Value is about good / bad, appropriate / inappropriate, proper / improper [6]. Cultural values are conceptions existed and preserved by a person or by most particular cultural societies collectively on what is considered to be highly valuable and important in life, about the degree of expected significance and behavior [7]

Values basically represent the views or beliefs of a person or a group of people that something is valuable, useful, appropriate and properto be maintained and accomplished [8]. According to counselor, the individual is essentially good and able to change. Counselor believes that the counselee might change, though sometimes the environment is quite influential. It is logical because almost all behavior is the result of learning and the environmental impact is highly substantial on the personality / human behavior. Therefore, a person can change depending on his or her own motivation and the surrounding environment.

Values are related to time orientation. Counselor tends to be in time and attempts to be always on timeto build trust for counselee. In an agrarian society, learning punctualculture is not easy. According to counselors, counselees tend to be on time, while some are unpunctual. Counselors tend to be oriented toward the present and the future, while counselees are oriented toward the past, the present, and the future. According to counselors, a number of counselees follow what people think, while some tend to follow what the group said. It is understandable, because someone will be ready to cooperate even sacrificing themselves for the group[8]. Counselors tend to adhere various world views, but there is also an ordinary and monotonous view of life. Sometimes this value is related to age, that the old age counselor tends to live a normal life and tends to be monotonous.

In counselor's view, counselees tend to willingly follow school rules and accept the social order and solidarity. In addition, they are easy to follow tradition, helpful, trustworthy and tolerant. This is understandable; they are in a favorite state school, so the culture of discipline has been ingrained from the beginning. Counselors tend to be provident, while counselees tend to be shortsighted. The result of [9] study explains that local tradition values are still held by villagers as informal education. This greatly affects the cultural transformation between generations, both vertical transmission and oblique transmission. [8] stated that the transmission process is achieved through enculturation and socialization.

Stereotypes also include in counseling constraints. Stereotype is an attitude barrier as it is formed and rooted so long that it is difficult to change [6]. In providing assistance services, counselors can basically accept different views due to different gender, religion, age, ethnicity, and social class. Although in terms of age differences, few counselors consider the counselee as their grandchildren, causing them toadviseinstead of to counsel. Consequently, the use of counseling techniques and approaches is ignored. Nevertheless in its development, counseling faces complex challenges due to rapid changes in various aspects of life, thus affecting the complexity of the problems of the counselee [10].

Social classes in society sometimes are able to limit relations and communication as well. Counselors can associate with individuals from different social classes, but some feel more comfortable hanging out with the same social class. This happens because there are times when counselors position themselves in their own social class. According to counselor, basically people are created equal and are not distinguished from their social class. Counselor's view on the relevance of education to social class is varied. Counselors tend to state that one's education is not related to social class, but social class affects the importance of 
education and determines the orientation of education. Likewise, counselor's view on the correlation between occupation and social class; occupation might determine the social class, as well as occupation might not related to one's social class. However, counselors tend to argue that income is not related to the social class. In general, one's education affects the pursued occupation. Commonly, most institutions or employment agencies fill the formation of employees by using educational requirements. Furthermore, it will affect the income earned sequentially. Thus, social classes appear in society, namely upper, middle and lower social class.

At present, ethnic diversity happens everywhere. Population mobility due to education and job demands greatly affect the diversity of race/ethnic group. Cultural differences existing between races / ethnic groups are of concern in the lives of individuals. Basically, counselors feel comfortable with the different ethnic group, but some still feel less comfortable with the different ethnic group. Counselors can accept different ethnic groups and their habits. According to the counselor, the minority group can be independent, yet some still need to be assisted. On the other hand, counselors stated that the majority group are independent enough and do not need much help. There is a tendency that the majority is lacking empathy, only see things from their point of view and less able to see from the other side. This can happen to counselors and counselees, as well as in many aspects of life.

Role differences between men and women indeed exist from childhood, both in general and in particular. This affects the understanding, attitude, and manner of acting. Based on the information obtained from counselor, counselee feels comfortable with male and female counselors. Counselors argue that female counselors are more comfortable to talk to than male counselors. According to counselor, male counselees and female counselees tend to be comfortable to talk to. However, female counselees tend to be more open, prompt and comfortable to tell the problem in detail. They love to come alone to vent. The development of the role of men and women in Indonesian culturewhich is supported by the developmental characteristics as well might affect the attitude of male and female counselees.

The age difference between counselor and counselee spread wide. This age factor affects many things. According to counselor, counselee feels comfortable with a young counselor as well as with an old age counselor. Counselors explain that both young and old counselors are easy to talk to, because what counselees need is the one who can keep a secret. Young and old counselors tend to understand counselees, even though some assumes that the old ageis more experienced and knowledge able. Occasionally counselors are able to understand, but difficult to accept. Confidentiality in the counselingis a must in order to build trust and maintain the service quality standards. Different ages affect perspective, mindset, behavior, and manner. Adult people are apt to give advice and not be able to listen to what adolescents say. This can cause assistance service to be unsuccessful.

Meanwhile, the counselor's view about the counselee is that adolescents tend to be difficult to understand because they want to show their true identity. Adolescents are not so easy to talk to, are still looking for identity and are susceptible. According to counselor, adolescents tend to have numerous needs. Adolescents want to show their existence and seek identity. It is along with the need for recognition, appreciation, and actualization [5]. In counselor's view, adolescents tend to have a lot of problems. They are susceptible, vulnerable, and have difficulties in refusing their group's demands. This kind of occurrenceis related to adolescents' search for identity. Some counselors argue that adolescents' problems are complex. The perception of the problem is not always the same between the counselee with an adult or teacher.

Efforts done to overcome the problem of sexuality are common issues which become the subject of study in counseling. The problem of sexuality is about acknowledging sexual feelings, absorbing those feelings and shaping one's selfimage, and making decisions about how to act on the basis of feelings and identity. This process is quite difficult when people are getting adequate support from others. They can be in doubt causing the directions taken against fundamental and highly preserved norms of society [2].

Sexual preference in Indonesia begin to be vaguely revealed and acknowledged by society (albeit very limited or forced), compared with a few years ago. That kind of society change affects the counseling, because counselors might deal with counselees experiencing situations with regard to sexual preferences. It might cause a clash in counseling because counselor is unlikely to be aware of the emerging values or the counselor has a different orientation about the problems faced by the counselee. Based on the data obtained, some counselors can understand the existence of lesbian, gay, bisexual, and transgender (LGBT), and some counselors are unable to understand LGBT. Most counselors tend not to accept the LGBT. According to most counselors, LGBT violates social norms and violates the law, yet few consider that LGBT is socially and legally acceptable to some extent. 
Most counselors state that they are not willing to make friends with LGBTpeople, while some take the opposite side. Although counselor cannot accept LGBT, but counselor admit that LGBT people should be assisted. Aligned with that, most counselors state that LGBT student should not be expelled from school, while some argue that LGBT students should be expelled from school.

In Indonesia, LGBT is not legally facilitated, but alternative lifestyle orientation indeed exists. There is a group of transvestite and gay community who have publicly declared themselves. It is not easy for counselors who mostly adhere to the traditional lifestyle, i.e. marrying the opposite sex and having children.

The counseling profession has reached a position where all the interests of individuals and society are served more efficiently in a pluralistic culture, which considers the validity of various lifestyles. In other words, the overall interests of individuals and society are served more effectively in a pluralistic culture that recognizes the validity of multiple lifestyles than in a culture that has a narrow view of acceptable lifestyle [2]. According to counselor, they often eat at home rather than dine out. Some counselors tend to buy goods or food in traditional markets, as well as in supermarkets. They tend to buy items at the store rather than online. Most counselors tend to feel comfortable using any brand item, while some have preferences for particular brand. For the use of mobile phone, some counselors tend to be comfortable using any brand name, while some use certain brand. These kinds of tendency also occur in the choice of counselors' vehicle. Some counselors tend to ride a motorcycle with a particular brand, and some feel comfortable driving any brand. This involves the usage habits; they feel comfortable only with a particular brand and are not willing to change. Sometimes adults are not easy to adjust with other brand new goods, such as mobile phone and motorcycles. Some counselors feel comfortable eating in any stalls/depots/restaurants, while some are comfortable eating in a particular depot/restaurant. The considerations in selecting the eating places are more of the hygiene, easily accessible, safe, and at reasonable prices, not a matter of prestige.

\subsection{Culture of Counselees in Counseling Services}

Language as a communication tool in counseling influences the process and results of counseling. Counselors' and counselees' language are affected by many factors. Factors shaping language development are biological, behavioral and environmental influences. The child's age, health and physical condition, the child's intelligence, socio-economic status, gender, environment, motivation and desire to communicate, family size, birth order, child training methods, multiple births, the relationship with peers, and personality bring about individual differences in language ability/development [5].

In terms of language, counselee considers that counselor's language is easy to understand, because counselor uses Bahasa Indonesia. Counselor uses the same language as the counselee. According to the counselee, some counselors use different dialects with them, while some counselors usethe same dialect as the counselee. Both counselors and counselees have good language mastery. Some counselees state that counselors'language tends to be monotonous, while some argue that counselors' language varies. Counselors use Bahasa Indonesia, Javanese, and sometimes slang. In contrast, counselee languages tend to vary, and some are rather monotonous. Counselor and counselee tend to be rich in expression. According to some counselees, counselors and counselees use slang in counseling occasionally, but some suggest that the counselor and counselee quite often use slang. During counseling process, apparently counselors and counselees tend to use standard language that is Bahasa Indonesia which sometimes seems formal and incoherent.

Counselees'view of value is not much different with counselors' view. In regard to the view of value, counselee believes that basically a person is well-behaved, but some are terrible as well. Counselee states that a person can be badly behaved because of the environmental influences. People are always able to change. Counselee believes that someone can change depending on what $\mathrm{s} / \mathrm{he}$ is thinking and comprehending. Counselee's time orientation is similar to counselor's orientation. Some are punctual, while some are not. Counselor and counselee tend to be oriented in the present and occasionally look at the past. The future is commonly used to formulate a plan of action. Some counselees say that they follow not only what they thought, but also what their group says. Counselees tend to have various lifestyles, but stay just the way they are. They are prone to follow the tradition and to accept social order and solidarity, but tend to be difficult to follow school rules. According to counselees, counselors and some counselees tend to be broad-minded, while other counselees tend to be narrow-minded.

Related to the behavior of rules obedience, the findings of [11] research revealed that there were some school rules that were violated by most students, but the behavior was included in small 
offenses category. The most common self-discipline problems were: joking during class $(95.45 \%$ of students), cheat or helping their friends in cheating ( $82.27 \%$ of students), and getting school equipment behind $(75.46 \%$ of students). Basically, counselees tend to follow the school rules. Learning environment and disciplinary habits have made counselees trained with positive characters.

Principally, both male and female counselee tends to accept opinion from different sex. They can also accept thoughts from different religion, age, and social class. However, only some counselees are able to accept ideas from different ethnic group. Data about this stereotype is very relative and subjective. In reality, high school counselees are sometimes very easily provoked in conflicts, fights, bullying practices, and other unexpected behavior.

In regard to social class, counselees consider they can socialize with people from different social classes, and assume that basically all people are equal. According to some counselee, education, occupation, and income of a person are not related to social class. However, some assumes that education is related to social class. This sometimes does not correspond to real life. The creation of groups due to similar interests and the use of social media facilities (WhatsApp group, Facebook) will affect the development of high school students.

In terms of race/ethnic group views, counselees are basically inclined to accept different race/ethnic group including their habits. However, some counselees feel comfortable with different race/ethnic group, while others do not. Student placement in majors, comparative study activities, student exchange programs, and other similar activities are some strategies to teach counselees to have knowledge of the diversity of groups/races/ethnicities and their cultures. Thus, it is hoped that counselee will reach the competency standard of ethical conduct foundation independence, with the objective of recognizing the need to comply with the norms of behavior, understanding the diversity of behavior rules in the cultural context, and performing the selfconsideration of the fundamental norms (MoNE, 2008).

Counselee believes that both minority and majority groups can be independent and also need much help. As Locke (1986) points out, the fundamental basis for cross-cultural engagement is the recognition of group identity and individual differences. Being tolerant of these two standards is an ethical necessity for the counselor. In Indonesia, which consists of various races or ethnic groups, the differences vary greatly. These ethnic differences are often an inhibitor of the counseling process, because each ethnic group has its own habits, philosophy of life and different cultural values, which needs to be understood by the counselor. Applying multicultural awareness owned by the counselor, it is hoped they could resolve this conflict. Currently, intertribal and community conflicts incline to arise.

With regard to gender, counselees tend to feel comfortable with male counselors and they state that male counselors are easy to talk to. Counselees also feel comfortable with female counselors, thoughfew feel uncomfortable. Some counselees think female counselors tend to be nice to talk to, but some say they are hard to talk to. In general, counselees consider both male and female counselors are nice to talk to.

Concerning age factor, counselees are more comfortable with young counselors. They consider younger counselors are easier to talk to because they both have less generation gap. According to counselee, young age counselors tend to understand them. Some counselees still prefer talking to older counselors. However, some counselees state that older counselor is hard to talk to and prefers to advise. Counselee asserts, as if $\mathrm{s} /$ he speaks one word and the counselor answers with too many words. Older counselors tend to be difficult to understand counselees. Some counselees argue that adolescence tends to be easy to understand and to talk to, whereas some say they are rather difficult to understand and talk to. Most of them cover up the experiencedproblems. They confirm the opinion that adolescence tends to have many demands and problems.

With regard to sexual preference, some counselees can understand LGBT, while some cannot apprehend LGBT. They tend not to accept LGBT. According to the counselee, LGBT violates social and legal norms. Counselees confirm that they could not make friends with LGBT people. Some counselees state that LGBT people need to be helped, while some say they do not need to. Some counselees argue LGBT students should be expelled from school, while some thinks otherwise. There is an iceberg phenomenon that describes the existence of this alternative lifestyle. In schools, there are also students with that kind of orientation and sometimes other students recognize it.

The last is description related to lifestyle from counselee. According to counselee, they habitually eat at home. Some of them like to buy goods/food in traditional markets and others buy in supermarkets. They tend to buy items in the store rather than online, because they can choose freely and know the real goods. Some counselees can comfortably wear goods with any brand, whilesome prefer a particular brand. For the use of mobile phone and motorcycles, some counselees use certain brand, while others choose any brand. Some counselees are comfortable 
to eat at any food stall / restaurant, while some eat at certain restaurants. Counselee argues that certain brand makes no difference and the brand does not define a person. Related to lifestyle, a study found that many students in their teens appeared to have a consumerist mindset. Spending intelligence, cultural wisdom and local wisdom play a significant role in the choice of being consumerist[12]. Nowadays, lifestyle changes have been facilitated by various parties, including the appearance of Go-Jek companies that can transport people, goods, food and others.

\section{CONCLUSIONS AND SUGGESTIONS}

\subsection{Conclusion}

From this cultural study of counselors and counselees in counseling research, it can be concluded that counselor culture in counseling relating to language, values, stereotypes, social class, race or ethnicity, gender, age, sexual preferences, and lifestyle, are very wide-ranging. Cultural descriptions on these aspects vary greatly. It seems that counselor's age, sex, lifestyle, and work environment provide enough enrichment to the cultural explanations. Similarly, counseling cultures in counseling with regard to language, values, stereotypes, social class, race or ethnicity, gender, age, sexual preferences, and lifestyle vary widely. Class X, XI, and XII students'data sources provide information about how unique things are during counseling. The value-loaded situation in the relationship of counselor and counselee in counseling is very influential on the success of counseling.

\subsection{Suggestion}

It is suggested that cultural differences should be used as an enrichment of counselors' understanding and experience in providing counseling. Counselors need to refine their awareness of the aspects described. The willingness of counselors to put themselves in the counselee's position can help to bridge the differences that exist between counselor and counselee. Furthermore, the findings of the research can be used as additional discourse for the Foundation of Socio-Cultural of Guidance and Counseling, Multicultural Counseling, and Field Study and Practice (KPL) of Guidance and Counseling course. It is hoped that further research can be done for counselor and counselee data sources in Islamic high school and vocational school by adding people with disabilities or special needsaspects. The purpose of data sources addition is to obtain a cultural picture on those educational units. Furthermore, the aspect of students with special needs should be recognized in relation to the existence of inclusive schools.

\section{REFERENCES}

[1] Permendikbud RI Nomor 111 Tahun 2014 Tentang Bimbingan dan Konseling pada Pendidikan Dasar dan Pendidikan Menengah.

[2] Brown, Duane dan Srebalus D. J. 1988. An Introduction to the Counseling Profession. Boston: Allyn and Bacon.

[3] Huberman. Michael A. \& Miles, Mathew.1994. Qualitative Data Analysis. New York: Sage Publications Inc..

[4] Flurentin, E. \& Santoso, D. B. 2015. Konflik Budaya dan Kaitannya dengan Proses Pemandirian Peserta Didik dalam Layanan Konseling. Malang: Jurusan BK FIP UM

[5] Triyono, dkk. 2012. Perkembangan Peserta Didik. Malang: FIP UM

[6] Flurentin, E., 2001. Konseling Lintas Budaya. Malang: FIP UM.

[7] Koentjaraningrat, 1985. Kebudayaan, Mentalitas dan Pembangunan. Jakarta: PT Gramedia.

[8] Atmoko, A. 2014. Landasan Sosial Budaya Bimbingan Berbasis Pemecahan Masalah. Edisi Revisi. Malang: Jurusan BK FIP UM

[9] Zulkarnain. 2013. Telaah Nilai-nilai Tradisi Lokal Masyarakat Desa sebagai Pendidikan Informal dalam Membina Keharmonisan Masyarakat. Jurnal Ilmu Pendidikan, 40 (1): 62-71.

[10] Ramli, M. 2016. Perkembangan Mutakhir Teori dan Pendekatan Konseling Sekolah: Konseling Ringkas Berfokus Solusi. Makalah disajikan dalam Pelatihan Teknik-teknik Konseling Berfokus Solusi bagi Mahasiswa Jurusan BK FKIP UTP Surakarta tanggal 8 Maret 2016 di UM.

[11] Fauzan, F. dan Bisri, M. 2013. Self Discipline Siswa sebagai Masalah dalam Bimbingan dan Konseling: Gambaran dan Model Batuannya. Jurnal Ilmu Pendidikan, 40 (1): 16-23.

[12] Mappiare, A. dkk. 2014. Rumusan Sistematis Budaya Nusantara sebagai Konten Media Bimbingan dan 
Konseling Multibudaya. Jurnal Ilmu Pendidikan, 41 (1):

$15-24$. 